\title{
Abundance of Mangrove Crab (Scylla Serrata) Its Linkage With The Bio-Physical Karasteristics Of Mangrove Forest In Karangsong Sub-District Indramayu District.
}

\author{
Donny J. Prihadi ${ }^{1,2}$, Zhang Gunghai ${ }^{2}$, Noir P. Purba ${ }^{1}$, Indah Riyantini ${ }^{1}$, Vicky \\ Soemantrie ${ }^{1}$ \\ ${ }^{1}$ Department Marine Science, Faculty of Fishery and Marine Science, University Padjadjaran, \\ Indonesia \\ ${ }^{2}$ Tourism Management, College of Management, Ocean University of China, China \\ Email: donny.juliandri.prihadi@unpad.ac.id
}

\begin{abstract}
Mangrove ecosystem is a habitat of mangrove crab (Scylla serrata). This research was conducted in mangrove ecosystem area of Karangsong Village, Karangsong Sub-district, Indramayu District. The purpose of this research is to know the abundance of mangrove crab, mangrove ecosystem condition and mangrove ecosystem relationship with mangrove crab in Karangsong mangrove ecosystem. The method used is descriptive explorative and station determination is done by stratified random sampling method. The results of the study found two types of mangroves namely Rhizopora mucronata and Avicennia marina. The mangrove conditions at the observed stations were classified as rare (broken). Mangrove density at station 1 has a value of 360 ind / ha, station 2 is 380 ind / ha, station 3 of 860 ind / ha and
\end{abstract}


station 4 has a value of 480 ind / ha. Abundance of mangrove crabs at station 1 amounted to 280 ind / ha, station 2 as many as 340 ind / ha, station 3 valued 0 ind / ha and station 4 of 60 ind / ha. The relation between mangrove density with abundance Scylla serrata level of tree has value of coefficient of determination (R2) 0,10529 mean that between density of mangrove trees with abundance of mangrove no relation.

Keywords: Mangroves, Mangrove Crabs, Density, Abundance

\section{Preliminary}

Mangrove forest is a renewable resource. Vegetation of forest composition consists of more than 60 species of trees and shrubs, and more than 20 species of plants that are mangrove associations. In addition to the vegetation found in mangrove forest there are more than 2000 water biota that depend on the existence of these forests, such as fish, invertebrates, and epiphytic plants (Dahuri 2003). Mud crab is an animal that is often found in all coastal enclosures are overgrown with mangroves. These animals have special features of having a fine convex carapace, a carapace width of one and a half of body length, there are three pairs of road legs, perfection of paddle feet (swimming legs), and cheliped drinks (Siahainenia 2008).

Mangrove crabs have levels in the phase of their lives, because they have an effect on their natural eating habits. At the larval level of mangrove crabs include the eating of various planktonic organisms such as diatoms, molluscs and worms. At the level of young crabs, the type of natural food of mangrove crabs are small fish, shrimp and molluscs, whereas in mature mangrove crab is scavenger organism (Kasry 1996 and Queensland Department of Primary Industries 1989b in Siahainenia 2008) Arriola (1940) in Siahainenia (2008), states that mangrove crabs are omnivorous-scavengers, eaters of all kinds (cannibals, algae eaters, woody remains and other decomposing objects). 


\section{Materials and metedology}

\section{Time and place.}

Observation of samples was conducted in the laboratory of Marine Science and Technology Faculty of Fisheries and Marine Sciences Padjadjaran University. This research was conducted in July - October 2017.

\section{Tool and materials}

The tool used in this research is roll meter, mangrove identification book, GPS, raffia rope, sewing meter, stationery, bucket, shovel, 1x1 transect, crab identification book, camera, $\mathrm{pH}$ meter, thermometer, refractometer, DO meter, plastic ziplock, shieve shaker, piston core and analytic scales. The material used is for the measurement of physical-chemical parameters performed directly (in situ) and substrate analysis done in the laboratory (ex situ).

\section{Method}

Mangrove crabs were caught using fish traps and bubbles from three sampling points, sampling of mangrove crabs was done in the afternoon, bubu in pairs and catches were taken. Repetition is done three times, each plot at each point is installed 2 pieces of bubu. The caught mangrove crabs are separated according to each station, then counted the number of individuals per-type, measured by the length of the crack, and weighs the body weight to know the relationship of the krapas with the weight of its body.

Mangrove data collection is done by counting the number, type, and measuring the diameter of trees, seedlings, and seedlings, taking mangrove data using quadratic transects with 10x10 $\mathrm{m} 2$ each for tree, $5 \times 5 \mathrm{~m} 2$ for tillers and $1 \times 1 \mathrm{~m} 2$ for seedlings. Taking of mangrove data is done once at the beginning of the research to identify.

\section{Data analysis}

\section{Abundance of Mangrove Crab, As Well As Density Type Mangrove.}

Abundance of mangrove crabs can be measured using the formula:

$$
\mathrm{N}=\frac{\sum n i}{A}
$$

Information

$\mathrm{N} \quad=$ Abundance of mangrove species crab i 
$\sum$ ni $\quad=$ Number of Individual types i

A $\quad=$ Extensive plots of sampling

Analyze data on density of mangrove species (Siahainenia 2008):

$\mathrm{K}=\frac{N}{A}$

Information :

$\mathrm{K}=$ density type $\mathrm{i}$

$N \quad=$ the number of type i stands

A $\quad=$ Unit area station measured

\section{Mangrove}

\section{a. Density and Relative Density}

Density $\left(D_{1}\right)$ is the number of type I stands in a unit area (English et al., 1994):

$$
D_{i}=\frac{n i}{A}
$$

Information :

$\mathrm{D}_{\mathrm{i}}=$ Density of type $\mathrm{i}$

$\mathrm{N}_{\mathrm{i}}=$ Total number of individuals of the type

$\mathrm{A}=$ The total area of the sampling

\section{Relationship between Density of Mangrove Crab with Mangrove Density}

The relationship between two or more variables is seen by using regression analysis. The relationship between two variables can be linear when studied in short intervals, but will show curvature when the interval studied is quite large (Steel and Torrie, 1980). Regression analysis yields regression coefficients and correlation coefficients. The correlation coefficient (R) expresses the closeness of the relationship between two independent and free variables 
(Y). To see the correlation between density of biota molluscs with density and mangrove INP used Non Linear analysis. This regression analysis takes the model with the largest correlation coefficient with the aim of obtaining a more precise curve and also for eliminating or minimizing errors. The formula used by Steel and Torrie (1980) are:

$\mathrm{Y}=\boldsymbol{\beta}_{0}+\boldsymbol{\beta}_{1} \mathrm{X}+\ldots+\boldsymbol{\beta}_{n} X^{n}$

Information :

$\mathrm{Y}=$ Biota Density

$\beta=$ Regression coefficient

$\mathrm{X}=$ mangrove density (trees, stakes, and seedlings)

$\mathrm{N}=\operatorname{order}(\mathrm{n}: 1,2,3 \ldots \ldots \mathrm{n})$

\section{Results and Discussion}

\section{Condition of Water Quality and Substrate}

Water quality and substrate measurement results obtained values of each parameter presented in table 2 below:

Table 1. Physical and Chemical Parameter Measurement Results

\begin{tabular}{llllll}
\hline St & $\begin{array}{l}\text { Temperature } \\
\left({ }^{\circ} \mathrm{C}\right)\end{array}$ & Salinity (ppt) & DO $(\mathrm{mg} / \mathrm{L})$ & $\mathrm{pH}$ & Type Substrate \\
\hline 1 & 30,33 & 28 & 6,4 & 7,5 & Sand, muddy \\
2 & 29,5 & 27 & 5,2 & 7,4 & Sand,muddy \\
3 & 30,5 & 29 & 5,8 & 7,33 & Sand \\
4 & 30 & 28 & 5,3 & 7,5 & Sand,muddy \\
\hline
\end{tabular}

Based on the measurement results, the water temperature is $29.5-30.33^{\circ} \mathrm{C}$. Station 1 of $29.5^{\circ} \mathrm{C}$ and the highest temperature of $30.33^{\circ} \mathrm{C}$ found in station 2 . This is caused when the temperature is taken in the afternoon and done in the area that is slightly open or around the mangrove less tightly, so the waters are still feels hot and absorbs more sun. According to the quality standard of the decree of State Minister of environment number 51 year 2004 for 
good mangrove ecosystem is $28^{\circ} \mathrm{C}-33^{\circ} \mathrm{C}$. According to FAO (2011) standards, mangrove crabs can tolerate and live [in waters with a temperature range of $25^{\circ} \mathrm{C}-35^{\circ} \mathrm{C}$. From these statements can be expressed temperature in mangrove forest waters Karangsong still in good condition and in accordance with for growth of mangrove crab. The temperature range is also in accordance with the conditions required by mangroves. Irwanto (2006) states that mangroves are found along tropical and subtropical zones, with temperatures of $19^{\circ}-40^{\circ} \mathrm{C}$.

The measurement of $\mathrm{pH}$ of Karangsong mangrove area ranged from 7.33 - 7.55. Differences $\mathrm{pH}$ in each station is not too drastic, $\mathrm{pH}$ average on each station has the same relative value. Each station has a $\mathrm{pH}$ approaching neutral $\mathrm{pH}$ (7) with an average $\mathrm{pH}$ of 7.3. Mangrove crabs can survive at a $\mathrm{pH}$ with a range of values of $7.2-7.8$. This means that the mangrove crab at the sampling site is still in good $\mathrm{pH}$ condition for its growth, because at the location of the mangrove crab data collection, $\mathrm{pH} 7$ is the most measurable. Based on KEPMEN LH no $51 / 2004$ about seawater quality standards for marine biota in mangrove ecosystems a good $\mathrm{pH}$ ranges from 7 to 8.5. According to FAO (2011) the $\mathrm{pH}$ suitable for the growth of mangrove crab is 7 - 9. It shows that ph in karangsong waters is good and suitable for the growth of mangrove crab. The $\mathrm{pH}$ also indicates that the location is particularly suitable for mangrove growth. Widiastuti (1999) who suggested that the water $\mathrm{pH}$ range between 6 to 8.5, is suitable for mangrove growth. Salinity of Karangsong mangrove forest ranges from 27-29 ppt. Station I has the lowest salinity value because its waters are more mixed with fresh water brought by the river. Station III is the one that has the highest salinity because at the mouth of the river allows high salinity sea water still dominate when mixed. Average water salinity overall is 28 ppt. Based on KEPMEN LH no 51/2004 about sea water quality standard for marine biota in mangrove ecosystem salinity good maximal range 34 ppt. Mangrove crabs survive on salinity of $10 \mathrm{ppt}-35 \mathrm{ppt}$, but mangrove crabs can grow and thrive in a temperature range of $15 \mathrm{ppt}-35 \mathrm{ppt}$. Water salinity data at the sampling location in the range of $27 \mathrm{ppt}-29 \mathrm{ppt}$ is the salinity condition that is still in optimal condition for the growth of mangrove crab. According to FAO (2011) the salinity suitable for the growth of mangrove crab is $20-35$. This shows that salinity in the waters of karangsong is good and suitable for the growth of mangrove crab. Based on the analysis of salinity measurement of each station is suitable for mangrove growth. This is supported by the opinion of Suryadi, (2004) which states that the mangrove ecosystem can grow in the salinity range of 10-30 ppt.

The results of the measurement of the DO parameters show the difference in values on each measuring station. Station II is the highest DO site with an average value of $6.4 \mathrm{mg} / \mathrm{L}$ 
and Station I is the location with the lowest DO with an average measurement of $5.2 \mathrm{mg} / \mathrm{L}$. Station II has the highest DO caused because it is in the area near the estuary that often occurs mixing the water period so as to increase the oxygen division in the waters. Based on KEPMEN LH no 51/2004 about sea water quality standard for marine biota in good mangrove ecosystem DO is around $5 \mathrm{mg} / \mathrm{ml}$. The appropriate FAO (2011) DO for the growth of mangrove crab is $5 \mathrm{mg} / \mathrm{L}$. It shows that the DO in the waters of karangsong is good and suitable for the growth of mangrove crab. The substrate characteristics of each station are similar to the muddy sand found in stations 1,2 and 4, the stations are close to rivers and ponds, so that the percentage of mud fraction is higher than in station 3 . The 3 substrate type stations are sand, at station 3 location is close to the coastline. The condition is in line with Pratiwi's (2009) statement that mangrove crabs (Scylla sp) live in sandy and muddy habitats, so that the substrate located at the study site is suitable and good for the life of mangrove crab (Scyla sp.). The muddy sand substrate is perfect for the life of Rhizophora mucronata and Avicenia marina. Amin et al (2015) cites that Rhizophora mucronata is particularly suitable for life on muddy sand substrate. Avicenia marina species are compatible with muddy sand substrate, especially at the forefront of the beach (Bengen 2004). Avicenia marina can also live on sandy substrates. According to Indah et al (2008) Substrates are dominant sandy is indeed a substrate that is very suitable for the type Avicennia sp. This is caused by the effective form of chicken roots as a sand trap.

\section{Mangrove Vegetation}

There are two types of mangroves found in the conservation area of mangrove karangsong namely Avicennia sp and Rizhophora sp. The four stations were overgrown by Avicennia sp types while Rizhophora sp grew only in stations 1 and 4 (Figure 1)

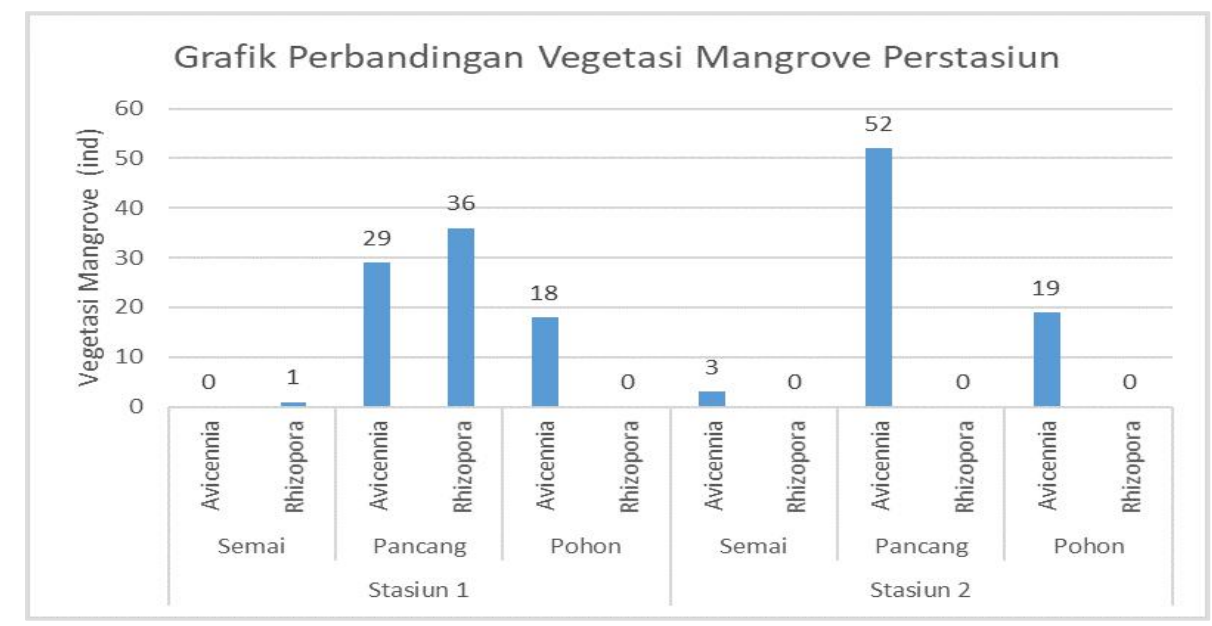




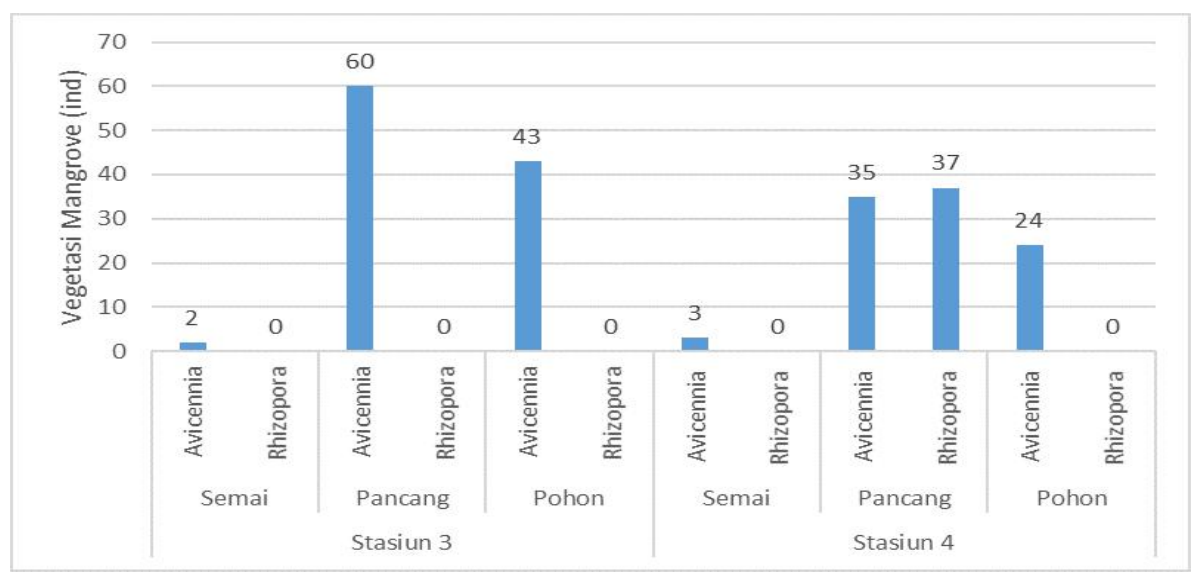

Figure 1. Graphic Comparison of Mangrove Vegetation of the station

Station 1 is in the tourist dock area and is overgrown by Avicennia marina and Rizhophora mucronata species. This location is found Avicennia marina species with the number of seedlings 0 stands, stakes 29 stands and trees 18 stands. Meanwhile, Rizhophora mucronata species in the seedling category were found with 1 stump, 36 sticks and 0 trees. Station 2 is located in the riverside area, this location is only overgrown Avicennia marina species with the number of seedlings 3 stands, stakes 52 stands and 19 trees stands. Station 3 is located in an area close to the sea, this location is only in grow Avicennia marina species with the number of seedlings 2 stands, stakes 60 stands and 43 trees stand. Station 4 is located in an area that cultivates a pond and is covered by Avicennia marina and Rizhophora mucronata species. This location is found Avicennia marina species with the number of seedlings 3 stands, stake 35 trees and 24 trees stands. Meanwhile, Rizhophora mucronata species in the seedling category were found with the number of seedlings 0 stands, stakes 37 trees and 0 trees stands. Avicennia marina is an indigenous species of mangroves in the village of Karangsong (Harahap 2001) so that it is more able to adapt to the environment, but according to Hutchings and Saenger (1987) A. marina is a species with wide ecological distribution, has a high temperature and salinity tolerance range, where it is and is often the dominant species. In the seedling stage $\mathrm{R}$. mucronata density is more dominant than the density of A. marina, even in station $1 \mathrm{R}$. mucronata is 200 , which means there is only one species occupying the area. This is because station 1 is an upstream area that receives more fresh water so that the salinity is lower. Hutchings and Saenger (1987) stated that R. mucronata found in areas with low salinity. 


\section{Mangrove Density}

The total density (stage of the tiller and tree of each species) can be seen in Figure 2.

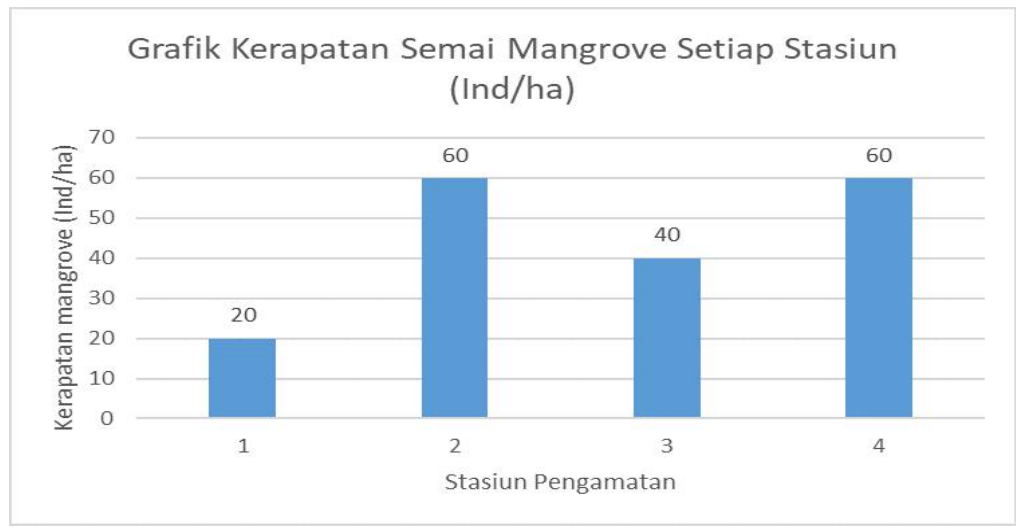

A

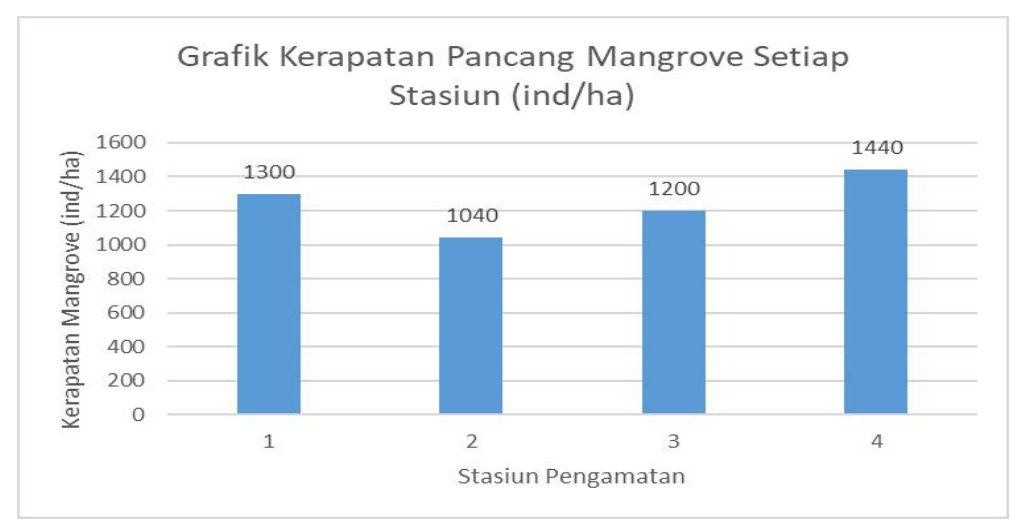

B

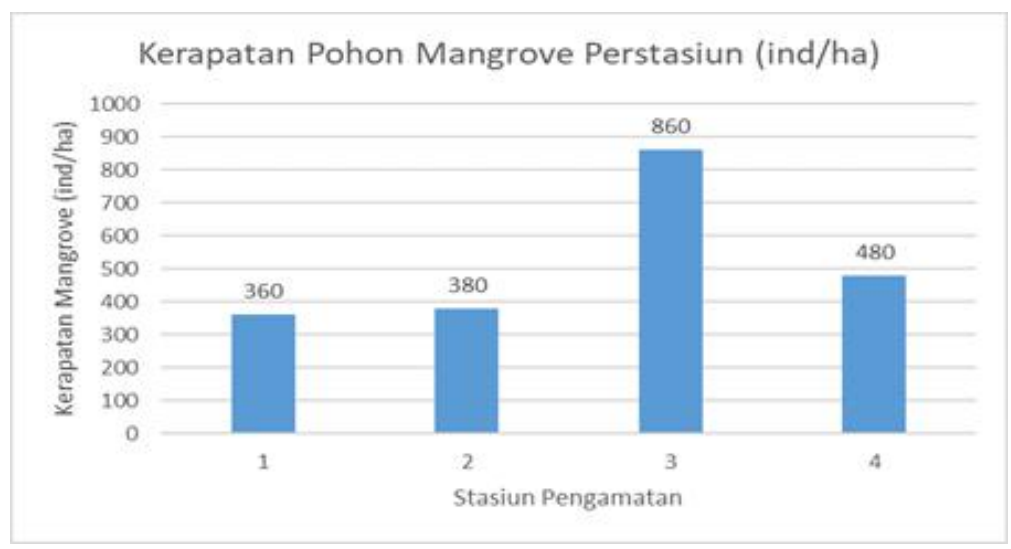

$\mathrm{C}$

Figure 2. Graph of Mangrove Density

Description: a) seedlings, b) stake, and c) trees

Tree mangrove density ranges from 360-480 ind / ha (Figure 2). Station 1 found Rhizopora mucronata and Avicenia marina with a total tree of 360 ind / ha. This shows that the keratatan in this location is rare (broken). The mangrove damage at station 1 is due to the 
contamination of residual fuel from the ship because the station is located near the boat dock. While the number of stake on this station reached $1300 \mathrm{ind} /$ ha and seedlings 20 ind / ha. The high number of stakes is the result of the rehabilitation process of karangsong mangrove forest. Station 2 has a density of 380 ind / ha and is classified as rare mangrove (damaged). The location of the station 2 is characteristic and its density value is not much different from station 1 because of its adjacent location. This station also suffered damage due to pollution of ship's fuel. The density at this station is $1040 \mathrm{ind} /$ ha and the seedlings are 60 ind / ha. The number of stakes caused by the reforestation process of karangsong mangrove forest. While seedlings are natural seeds of mangrove reproduction that has been there before. The value of mangrove station 3 density is 860 trees / ha. This station is only found mangrove type Avicennia marina. Sandy substrate is a substrate that is very suitable for the growth of Avicennia marina. The sandy substrate is less suitable for Rizophora sp growth because this type of sediment has a solid and hard surface. According to Noor (1999) Rizhophora sp. because this species is not able to grow in areas with hard substrate. Mangrove on the location is rare (broken). Station 3 has the highest density value compared to other stations due to its location adjacent to the coast but is not exposed to the tides so that this location is rarely accessed. The number of stake in station 3 is 1040 ind / ha which is rehabilitation and seeding vegetation as much as $40 \mathrm{ind} / \mathrm{ha}$. The value of mangrove density at station 4 is 480 trees / ha, and found two types of mangroves namely Rhizopora mucronata and Avicennia marina. The mangrove density at this station is categorized as rare (broken). The number of stake on the station is 1200 ind / ha and seedlings 60 ind / ha. The large number of stake in this location is also caused by the rehabilitation of mangrove forest.

Type A. marina and R. Mucronata highest at station 3 that is equal to 860 ind / ha. The density of A. marina tree species in each station is greater than the density of $R$. mucronata trees. The highest density of $A$. marina and $R$. mucronata tillers was at station 2 and 4 with density of 60 ind / ha. At station 1 found A. Marina with a density of 20 ind / ha. Mangrove density of A. marina and R. mucronata highest stage at station 4 with density 1440 ind / ha.

Based on the result of research known that Karangsong mangrove forest damaged. This is caused by pollution and at this location had occurred the function of mangrove ecosystem into pond land. 


\section{Abundance of Mangrove Crabs}

Each station has an abundance of varying mangrove crabs (Table 2).

\begin{tabular}{ll}
\hline Stasiun & Individu/ha \\
\hline 1 & 280 \\
\hline 2 & 340 \\
3 & 0 \\
4 & 60 \\
\hline
\end{tabular}

Station 1 has an abundance of 280 ind / ha while station 2 is 340 ind / ha. This location supports the life of mangrove crabs because it has a muddy sand substrate and is often inundated by water. The mangrove ecosystem provides a good habitat for mangrove crabs in the presence of a sheltered base substrate, a tree as a place to stick and an important abundance of organic detritus as a food source (Hamidy, 2010). Station 3 has an abundance of mangrove crabs of 0 ind / ha. This location is not found mangrove crab caused by the type of sandy substrates are quite hard because it is not inundated by water so that mangrove crab can not dig a hole to stay. Mud or muddy sludge substrate is a suitable substrate for the life of mangrove crabs and the presence of tides indicates that waterlogging in the ecosystem can directly affect the presence of mangrove crab (Gita 2016). Prianto (2007) said that the substrate around the mangrove forest strongly supports the life of mangrove crab, especially for marrying and doing a change of skin in the waters. Station 4 has Scylla serrata abundance of 60 ind / ha. This amount is much lower compared to stations 1 and 2 whereas the mangrove tree level at this location is higher. Taqwa (2010) which states that the highest abundance is in rare density, then decreases with increasing mangrove density. Increased mangrove density causes an increase in mangrove root cover to the bottom of the waters, resulting in abundance of mangrove crabs (Scylla sp.) Decreasing due to reduced area. 


\section{Mangrove Crab Connection With Mangrove Vegetation}

\section{Mangrove Crab With Mangrove Tree Level}

The relationship between abundance of mangrove crabs and the density of trees in the relation $y=0,5837 x+473,55$ The correlation coefficient value is -0.10529 (Figure 9). This correlation value is small to see the relationship between the two. This shows that the results obtained are not significantly different, meaning that between the density of mangrove trees with abundance of mangroves no relationship

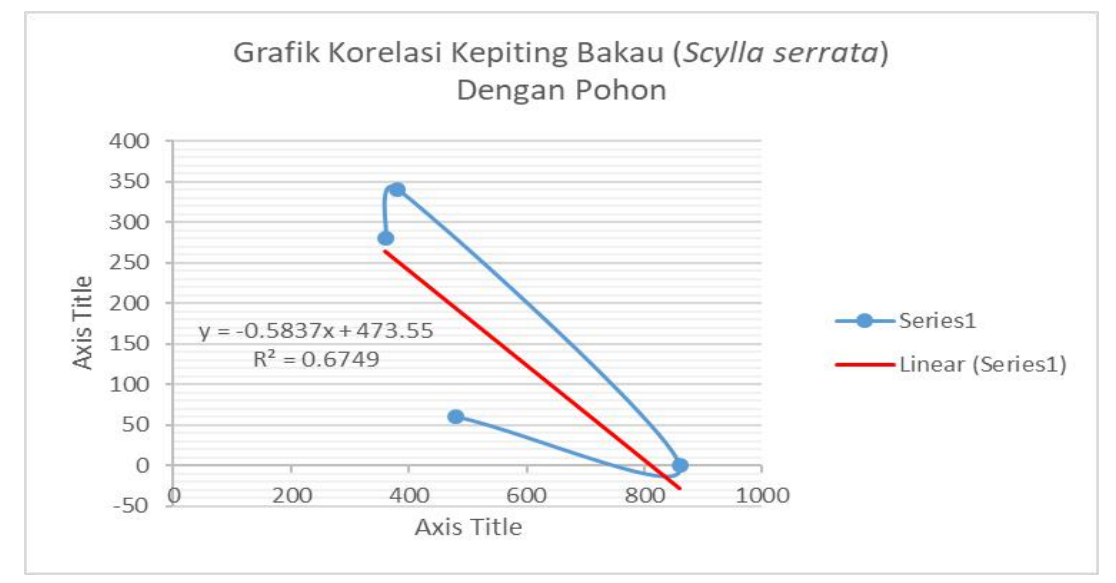

Figure 9. Graph of Mangrove Crab Correlation (Scylla serrata) With Tree

From the graph above can be seen, when the density is low the abundance of mangrove crab is high (station 1 and 2), whereas when the kerapatanya high abundance of mangrove crab is very low even none (station 3 and 4).

\section{Mangrove crab with mangrove piling level}

For the relation of density of pile level with abundance of mangrove crab obtained relation $y$ $=-0,5006 x+793,23$. The correlation coefficient value of -0.50996 is a small value. this means that the results obtained are not significant, meaning that there is no relationship between mangrove crabs and mangrove vegetation density (Figure 10). 


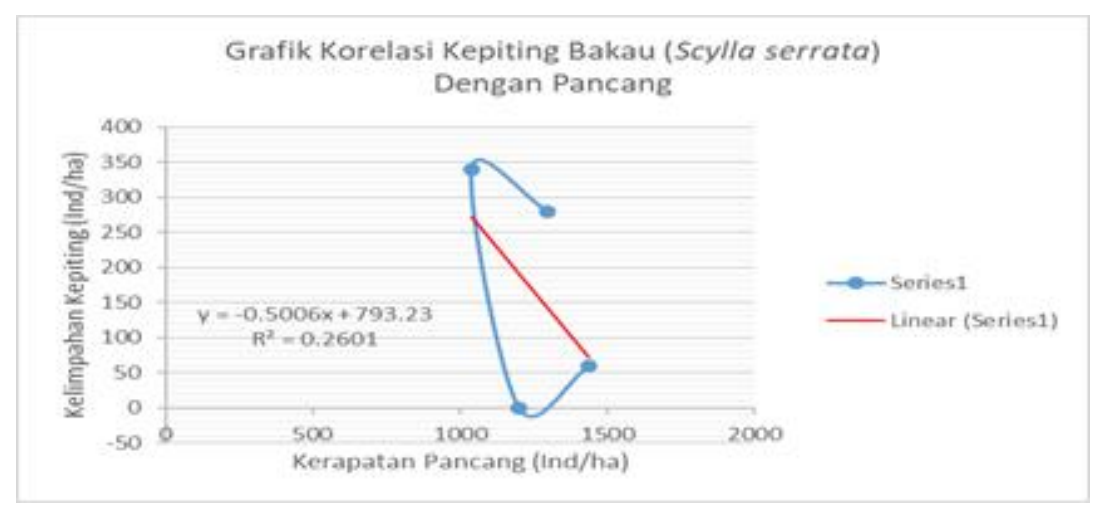

Figure 10. Graph of Mangrove Crab Correlation (Scylla serrata) With Pancang

\section{Mangrove crab with mangrove seedling level}

Mangrove crabs with mangrove seedlings As Figure 13 illustrates the relationship between seedling vegetation density and abundance of mangrove crabs obtained by the relation $\mathrm{y}=$ 0,9091x $+210,91$. Correlation coefficient value obtained -0.10529 (Figure 11). This means that the results obtained are not significant, which means there is no relationship between mangrove crabs with the density of mangrove vegetation level of stake.

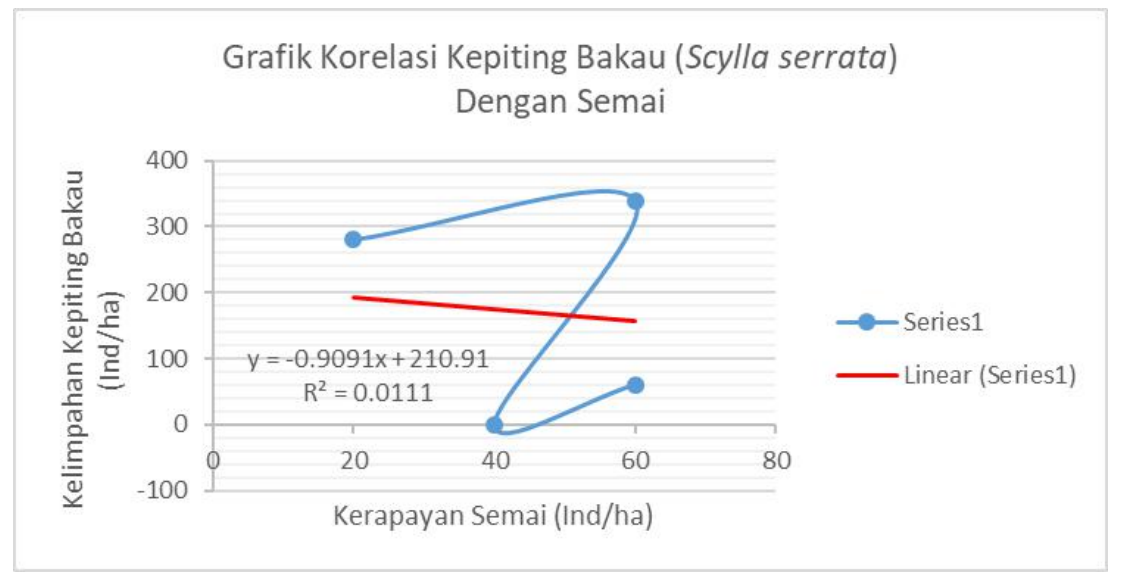

Figure 11. Graph of Mangrove Crab Correlation (Scylla serrata) With Seed

The three relationships obtained can be said that the relationship of mangrove density to the level of trees and tillers with abundance of mangrove crabs is not real or tend to be unrelated, while for the mangrove density relationship of seedling level with abundance of true mangrove crab. The mangrove density especially for tree level is closely related to the abundance of mangrove crabs when compared to mangrove seedling density, but seen from the graph the existing relationship becomes inconsistent. At the time of high tree density is actually relatively fewer abundance and vice versa when tree density is relatively low, the abundance of mangrove crab is high. This indicates that mangrove crab has adaptability to 
high environmental pressures so that the biota can survive in changing circumstances. The high density of seedlings is not an indicator of the abundance of mangrove crabs, because the more affecting the biota of the mangrove forest is the suitability of mangrove forest habitat and the supply of natural foods. Polynomial regression analysis gives different results, which affect the abundance of mangrove crabs in the vegetation level of seedling. This is probably caused by the growth of the seedling level not far from the tree or under the shade of the tree so that the leaves around the seedlings growing into many. The existence of human activities such as logging can also reduce the abundance of mangrove crabs because the environment will experience pressure and physical changes. Changes to the substrate occurs only the components and the content in the substrate does not change drastically. The research conducted by Nadia (2002) in Mangrove Habitat Karangsong Indramayu, West Java shows the same condition, when high mangrove biota density is small due to logging activity at the location causing biota that live in substrate disturbed.

\section{Conclusion}

Based on the result of the research, it can be concluded that the highest abundance is in the second station with the number 340 ind / ha, then the station one $280 \mathrm{ind} /$ ha and station four 60 ind / ha while the station three abundance 0 ind / ha. Mangrove conditions at all stations in karangsong are rare / damaged. The relationship of mangrove density to tree level and tillers with abundance of mangrove crabs was not real or likely to be unrelated, while for mangrove density relationship of seedling level with abundance of true mangrove crab.

\section{Suggestion}

Based on the research result, it is suggested that the number of observation stations need to be added to increase the data representation level. Further research on Scylla serrata in karangsong mangrove forest area on distribution, distribution pattern, diversity and uniformity is needed to improve data accuracy. 


\section{References}

[1] Amin, D. N, Irawan. H, Zulfikar, A. 2015. Hubungan Jenis Substrat Dengan Kerapatan Vegetasi Rhizophora Sp. Di Hutan Mangrove Sungai Nyirih Kecamatan Tanjungpinang Kota Kota Tanjungpinang. Jurnal FIKP UMRAH. Tanjungpinang.

[2] Bengen, D.G. 2000. Pengenalan dan pengelolaan ekosistem mangrove. Pusat Kajian Sumberdaya Pesisir dan Lautan IPB. 58 hal.

[3] Dahuri, R., 2003. Keanekaragaman Hayati Laut. PT. Gramedia Pustaka Jakarta.

[4] English, et, al,. 1994. Survey Manual for Tropical Marine Resources. Australian Institute of Marine Science. Townsville. Australia.

[5] Food and Agriculture Organization (FAO). 2011. FAO Data-bases and Data-sets. http://faostat.fao.org/site/569/default.aspx\#ancor. Diakses pada 3 Januari 2018 Pukul 21.04 WIB

[6] Gita, Rina SD. 2016. Keanekaragaman Jenis Kepiting Bakau (Scylla Spp.) Di Taman Nasional Alas Purwo Mangrove Crab Diversity (Scylla Spp.) In Alas Purwo National Park. Jurnal Biologi dan Pembelajaran Biologi. Volume 1 Nomor 2 Tahun 2016. (pISSN 2527-7111; e-ISSN 2528-1615).

[7] Hamidy, R. 2010. Struktur Dan Keragaman Komunitas Kepiting Di Kawasan Hutan Mangrove Stasiun Kelautan Universitas Riau, Desa Purnama Dumai. Journal of Environmental seiense. Program Studi Ilmu Lingkungan PPS. Universitas Riau.

[8] Harahap, M. K. 2001. Kajian Partisipasi Masyarakat dalam Pengelolaan Hutan Mangrove (Studi Kasus di Desa Karangsong, Indramayu). [TESIS]. Program Pascasarjana. Institute Pertanian Bogor.

[9] Hutchings P, Saenger P. 1987. Ecology of Mangrove. University of Queensland Press. St., Lucia. London. New York.

[10] Irwanto. 2006. Keanekaragaman Fauna pada Habitat Mangrove. Yogyakarta

[11] Kementrian Lingkungan Hidup RI. 2004. Baku Mutu Air Laut. Kepmen LH/51/2004.

[12] Nadia, Y. 2002. Analisa Komunitas Krustasea Berukuran Kecil (Famili Ocypodidae dan Grapsidae) di Habitat Mangrove Muara Sungai Bengawan Solo, Desa Pangkah Wetan Ujung Pangkah, Gresik, Jawa Timur. Skripsi. Program Studi Ilmu Kelautan.

[13] Fakultas Perikanan dan Ilmu Kelautan. Institut Pertanian Bogor.

[14] Noor, Y.R.M. Khazali, I.N.N. Suryadiputra. 1999. Panduan Pengenalan Mangrove di 
Indonesia. PKA/WI- IP, Bogor.

[15] Pratiwi, R., 2009. Komposisi Keberadaan Krustasea di Mangrove Delta Mahakam Kalimantan Timur. Makara, Sain, LIPI, Jakarta.

[16] Prianto. (2007). Dinamika-ku: jangan abaikan pelayanan. http://www.google.co.id/jangan/abaikan/pelayanan. Tanggal akses 11 Maret 2008.

[17] Siahainenia, L. 2008. Biologi Laut Kepiting di Ekosistem Mangrove Kabupaten Subang Jawa Barat. Disertasi. Institut Pertanian Bogor.

[18] Steel RGD, Torrie JH. 1980. Principle and procedure of statistics: A biometric approach. McGraw-New York.

[19] Taqwa, A. 2010. Analisisi Produktivitas Primer Fitoplankton dan Struktur Komunitas Fauna Makrobentos berdasarkan Kerapatan Mangrove di Kawasan Konservasi Mangrove

[20] dan Bekantan Kota Tarakan, Kalimantan Timur. Tesis. Program Pascasarjana, Universitas Diponegoro, Semarang, $64 \mathrm{hlm}$. 